\title{
Pembuatan Sabun Menggunakan Minyak Jelantah Guna Mengurangi Pencemaran Lingkungan
}

\author{
Mukhlison' ${ }^{1}$, Rochmat Khudlori², Dedy Setyawan $^{3}$ \\ ${ }^{1}$ Teknik Elektro, Universitas Islam Balitar, Jl. Majapahit No.2- 4, Kota Blitar, Indonesia 66137 \\ ${ }^{2}$ Ilmu Administrasi Negara, Universitas Islam Balitar, Jl. Majapahit No.2- 4, Kota Blitar, Indonesia 66137 \\ ${ }^{3}$ Teknik Elektro, Universitas Islam Balitar, Jl. Majapahit No.2- 4, Kota Blitar, Indonesia 66137
}

Correspondence: mukhlison@unisbablitar.ac.id

Received: 30 Juni 2021 - Revised: 01 Agustus 2021 - Accepted: 16 Agustus 2021

\begin{abstract}
Abstrak. Limbah minyak goreng yang langsung dibuang secara sembarangan ke lingkungan akan menyebabkan pencemaran lingkungan, menjadikan lingkungan kotor dan menjadi bahan pencemar bagi air dan tanah. Untuk mengatasi masalah terkait meningkatnya volume limbah minyak goreng yang tinggi, dilakukan kegiatan pengabdian masyarakat yang bertujuan untuk meningkatkan nilai tambah bagi limbah minyak jelantah dengan cara mengolah minyak jelantah tersebut menjadi sabun. Pelatihan mengenai pengolahan limbah minyak jelantah menjadi sabun yang ekonomis dan ramah lingkungan sangat bermanfaat bagi masyarakat Indonesia khususnya masyarakat di desa Blimbing. Pelatihan pembuatan sabun menggunakan minyak jelantah guna mengurangi pencemaran lingkungan sangat mudah dilakukan dengan alat dan bahan yang tersedia di rumah tangga. Selain itu, volume minyak jelantah yang terdapat di Desa Blimbing juga mendukung produksi pembuatan sabun sehingga peserta dapat dengan mudah mengaplikasikan keterampilan yang mereka dapat untuk diterapkan di rumah.
\end{abstract}

Kata kunci: Pembuatan sabun, minyak jelantah, pencemaran lingkungan

Citation Format: Mukhlison, Khudlori, R. \& Setyawan, D. (2021). Pembuatan Sabun Menggunakan Minyak Jelantah Guna Mengurangi Pencemaran Lingkungan. Prosiding Seminar Nasional Abdimas Ma Chung (SENAM), 89-97. 


\section{PENDAHULUAN}

Desa Blimbing merupakan salah satu desa di Rejotangan yang memiliki pertumbuhan penduduk yang signifikan, selain itu dunia usaha di desa Blimbing juga semakin cepat berkembang. Dengan banyaknya jumlah penduduk di Desa Blimbing mengakibatkan tingkat konsumtif di Desa blimbing meningkat. Dalam kegiatan rumah tangga, terdapat sembilan bahan pokok yang dikonsumsi oleh seluruh lapisan masyarakat khususnya di Desa Blimbing yaitu minyak goreng. Umunya masyarakat di Indonesia menyukai makanan yang digoreng karena menghasilkan cita rasa yang khas (Anastasia, 2018). Di Indonesia konsumsi minyak goreng mencapai 290.000 ton/tahun dan hal ini merupakan angka yang cukup tinggi. Konsumsi minyak goreng yang terus mengalami peningkatan pada akhirnya akan berdampak terhadap meningkatnya penggunaan limbah rumah tangga minyak jelantah yang dikonsumsi oleh masyarakat, apalagi penggunaan minyak jelantah secara berulang dan terus menerus akan memberikan dampak yang buruk bagi kesehatan maupun lingkungan (Hanum, 2016).

Pengertian minyak goreng sendiri yaitu bahan makanan yang berasal dari lemak tumbuhan atau hewan yang dimurnikan, berbentuk cair dalam suhu kamar dan biasanya digunaan untuk menggoreng makanan. Minyak goreng yang berasal dari tumbuhan biasanya berasal dari tanaman seperti kelapa, biji-bijian, kacang-kacangan, jagung dan kedelai (Ketaren, 1986). Minyak yang baik merupakan minyak yang di dalamnya mengandung asam lemak tak jenuh yang lebih banyak dibandingkan dengan kansungan asam lemak jenuhnya. Minyak jelantah atau limbah minyak goreng merupakan minyak yang diperoleh dari sisa proses penggorengan dan sudah dipakai berulang kali, karena hal tersebut maka asam lemak yang terkandung dalam minyak tersebut akan semakin jenuh dan akan berubah warna sehingga tidak sehat untuk dikonsumsi oleh masyarakat (Mardiana, et al 2020). Kualitas minyak goreng yang telah menurun akan mempengaruhi bau dan cita rasa makanan yang digoreng dalam minyak tersebut sehingga jika terus digunakan berulang kali, maka asam lemak yang terkandung akan semakin jenuh dan berubah warna. Minyak yang telah rusak atau biasa disebut minyak jelantah kurang baik untuk dikonsumsi.

Limbah minyak goreng yang langsung dibuang secara sembarangan ke lingkungan akan menyebabkan pencemaran lingkungan, menjadikan lingkungan kotor dan menjadi bahan pencemar bagi air dan tanah. Selain itu menurut penelitian yang dilakukan oleh Haryono et al. (2010) dijelaskan bahwa minyak jelantah yang dibuang ke perairan dapat 
menyebabkan rusaknya ekosistem perairan karena meningkatnya kadar Chemical Oxygen Demind (COD) serta Biological Oxygen Demind (BOD) yang disebabkan tertutupnya permukaan air dengan lapisan minyak sehingga sinar matahari tidak dapat masuk ke perairan. Limbah minyak goreng yang yang terserap ke tanah juga akan mencemari tanah sehingga menjadi tidak subur. Akan tetapi kurangnya pengetahuan masyarakat mengenai dampak pembuangan limbah minyak goreng terhadap lingkungan, masih banyak masyarakat yang membuang limbah minyak goreng begitu saja. Oleh karena itu, butuh suatu usaha untuk mengatasi masalah terkait pengelolaan limbah minyak goreng dengan melibatkan masyarakat luas sehingga limbah minyak jelantah dapat dimanfaatkan menjadi produk yang bernilai ekonomis.

\section{MASALAH}

Limbah minyak goreng memiliki kandungan asam lemak dari minyak nabati yang tinggi sehingga limbah minyak jelantah dapat dimanfaatkan menjadi sabun yang ramah lingkungan (Hanjarvelianti \& Kurniasih, 2020). Akan tetapi sejauh ini, masyarakat belum mengetahui potensi ekonomi dari limbah minyak jelantah tersebut. Masalah lain yaitu masyarakat belum mengetahui metode tepat guna pengolahan limbah minyak goreng sebagai bahan sabun. Oleh karena itu, untuk mengatasi masalah terkait meningkatnya volume limbah minyak goreng yang tinggi, dilakukan kegiatan pengabdian masyarakat yang bertujuan untuk meningkatkan nilai tambah bagi limbah minyak jelantah dengan cara mengolah minyak jelantah tersebut menjadi sabun. Pelatihan mengenai pengolahan limbah minyak jelantah menjadi sabun yang ekonomis dan ramah lingkungan sangat bermanfaat bagi masyarakat Indonesia khususnya masyarakat di desa Blimbing.

\section{METODE PELAKSANAAN}

Kegitan pengabdian masyarakat terkait pembuatan sabun dari minyak jelantah kepda masyarakat di Desa blimbing dilakukan pada tanggal 15 Juni 2021 pada pukul 13.00-14.30 WIB berlokasi di rumah salah satu warga yaitu rumah Ibu Anis. Adapun alur dalam kegiatan pengabdian ini melalui beberapa tahap kegiatan yaitu sebagai berikut :

a. Tahap Penyampaian Materi

Kegiatan penyampaian materi dilakukan untuk memberikan pengetahuan mengenai tata cara pembuatan sabun dari minyak jelantah. Pada tahapan ini peserta pengabdian diberikan modul terkait tata cara pembuatan sabun dari minyak jelantah.

b. Tahap Praktik 
Praktik pembuatan sabun dilakukan dengan tujuan agar peserta pelatihan memperoleh gambaran umum teknik pembuatan sabun dari minyak jelantah. Pada tahap ini selanjutnya peserta diberikan alat dan bahan untuk pembuatan sabun dari minyak jelantah.

c. Pembagian Kuisioner

Setelah proses pelatihan pembuatan sabun selesai, dilakukan pembagian kuisioner. Kuisioner dibagikan dan diisi oleh peserta sesuai dengan jawaban masing-masing. Tujuan dari pembagian kuisioner ini adalah untuk mengetahui sejauh mana pengetahuan dan pemahaman peserta terhadap cara pembuatan sambal yang tahan lama.

d. Evaluasi

Evaluasi dilakukan untuk melihat kemampuan yang dimiliki oleh peserta setelah pelatihan selesai.

\section{HASIL DAN PEMBAHASAN}

Pelatihan pengabdian masyarakat dengan judul "Pembuatan Sabun Menggunakan Minyak Jelantah Guna Mengurangi Pencemaran Lingkungan” dilakukan di Desa Blimbing tepatnya di salah satu rumah warga yaitu Ibu Anis, pada hari Selasa, 15 Juni 2021. Peserta pelatihan terdiri atas 20 orang yang merupakan warga sekitar Desa Blimbing. Peserta pelatihan dibekali dahulu mengenai bahaya pencemaran minyak jelantah bagi lingkungan maupun kesehatan dan cara pengolahan minyak jelantah sehingga bernilai ekonomis menjadi sabun.

Rangkaian kegiatan pengabdian masyarakat diawali dengan presentasi mengenai dampak negatif dari minyak jelantah yang dibuang sembarangan di lingkungan serta cara pengolahan minyak jelantah menjadi sabun. Dalam tahapan ini peserta diberi modul yang berisi tentang cara pembuatan sabun dari minyak jelantah yang tujuannya agar kedepannya peserta mudah untuk mempraktekkannya dirumah dengan mmebaca modul tersebut. Setelah presentasi selesai tim pengabdian masyarakat melaksanakan demonstrasi atau praktik tentang tata cara pembuatan sabun dari minyak jelantah. Selama proses demonstrasi peserta terlihat antusias untuk menyaksikan demonstrasi pembuatan sabun tersebut. Setelah proses demonstrasi pembuatan sabun dari minyak jelantah telah selesai para peserta juga terlihat antusias untuk mempraktikannya di rumah. Peserta juga diberikan 
alat-alat dan bahan untuk pembuatan sabun dari minyak jelantah. Adapun bahan dan alat pembuatan sabun dari minyak jelantah adalah sebagai berikut :

1. Minyak jelantah

2. Soda api

3. Air dingin

4. Panci

5. Sarung tangan

6. Botol aqua bekas (untuk cetakan)

Sebelum kegiatan berakhir, peserta pengabdian masyarakat diberikan kuisioner untuk melihat seberapa paham dan pengetahuan peserta tentang cara pembuatan sabun dari minyak jelantah setelah menerima materi dan melihat proses pembuatannya secara langsung. Berikut akan dijelaskan mengenai cara pembuatan sabun pada pengabdian ini, yaitu sebagai berikut :

1. Timbang minyak jelantah, soda api, dan air di wadah yang berbeda

2. Larutkan soda api ke dalam air, lakukan sedikit demi sedikit sambil diaduk. Untuk keamanan gunakan sarung tangan yang tebal.

3. Karena suhu soda api yang tinggi maka rendam larutan tersebut di baskom yang sudah diberi air es dan biarkan suhu larutan soda api turun hingga terasa hangat ditangan.

4. Masukkan larutan soda api ke dalam minyak jelantah dan aduk rata hingga mengental

5. Setelah mengental tuang ke dalam cetakan

6. Tunggu kurang lebih sekitar 24 jam

7. Keluarkan dari cetakan dan biarkan selama 1 bulan

Respon peserta dalam kegiatan pengabdian masyarakat sangat baik, terlihat dari antusiasme mereka dalam menerima semua arahan dari tim pengabdian serta keterlibatan secara langsung untuk ikut mengolah bahan menjadi sabun yang ekonomis. Para peserta aktif mengajukan pertanyaan ketika kurang memhami penjelasan dari anggota pengabdian. Mereka juga menyampaikan bahwa keterampilan dan materi yang mereka pelajari saat tahap presentasi sangat bermanfaat dan memacu untuk diaplikasikan dalam kehidupan sehingga dapat menjadikan minyak jelantah bernilai ekonomis dan lebih bermanfaat. 


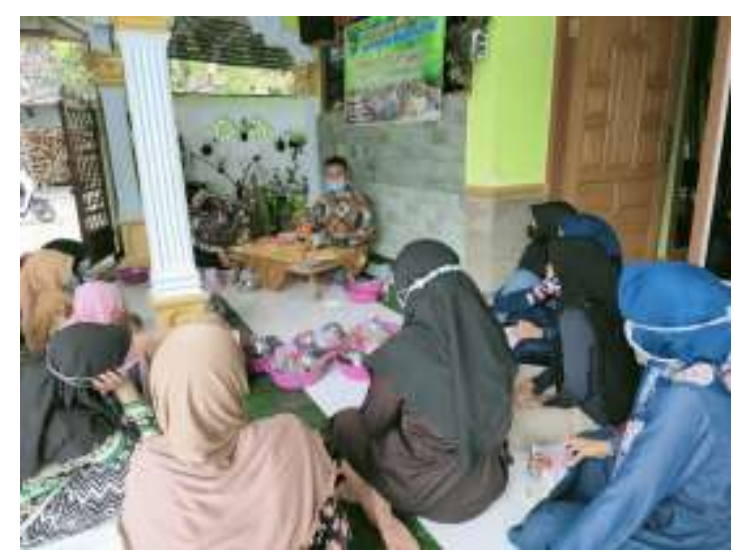

a

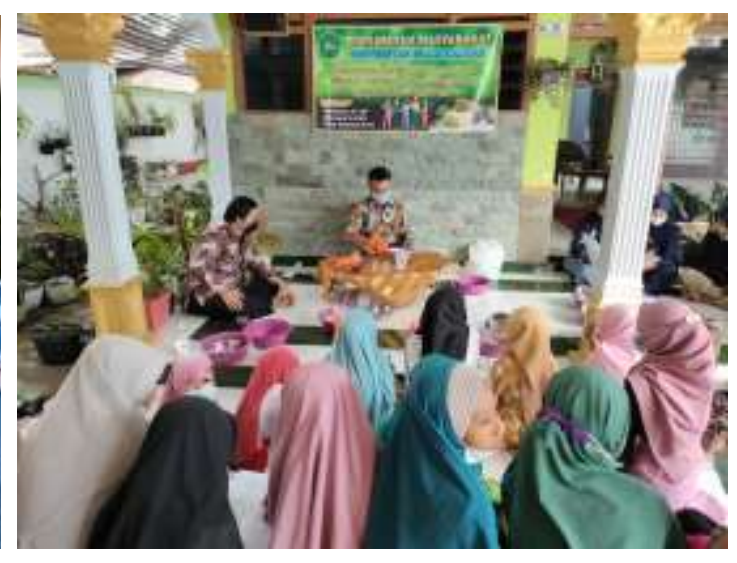

b

Gambar 1. Pemaparan materi dan praktik pembuatan sabun

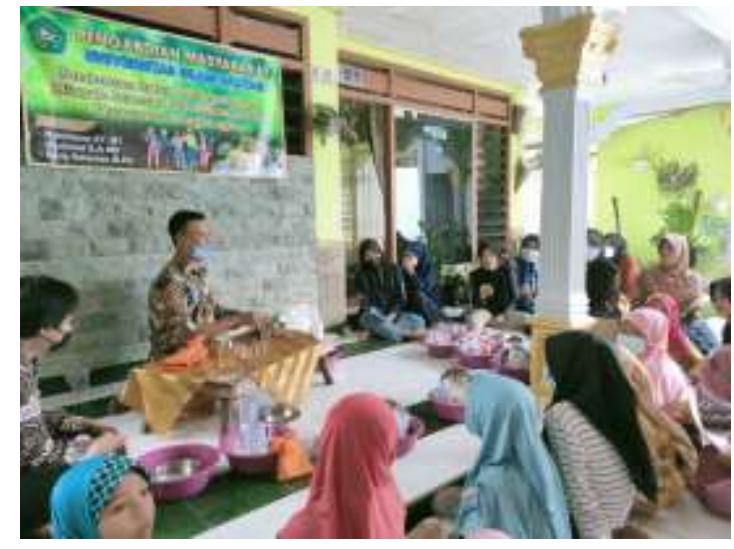

$\mathrm{a}$

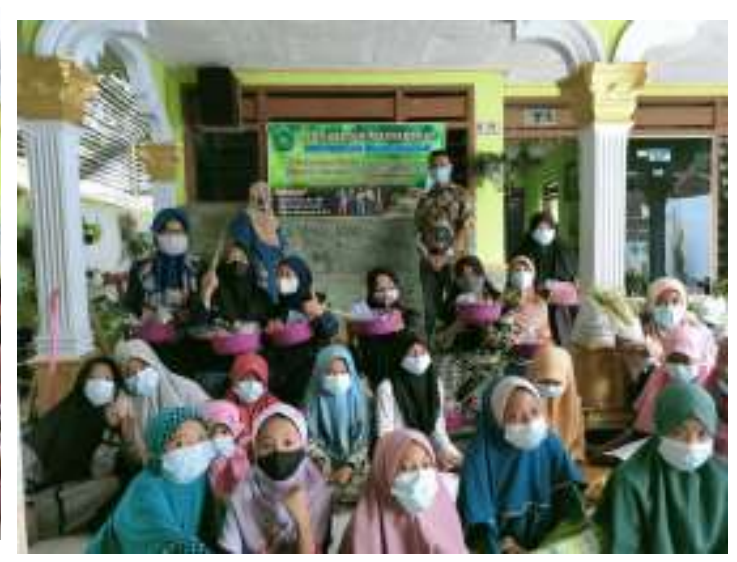

b

Gambar 2. Pembagian alat dan bahan pembuatan sabun

Evaluasi dalam pengabdian ini dilakukan untuk melihat seberapa besar peningkatan pemahaman peserta dalam pembuatan sabun menggunakan minyak jelantah guna mengurangi pencemaran lingkungan melalui angket penilaian akhir (post-test). 
Tabel 1. Angket Pengabdian Masyarakat Pembuatan Sabun Menggunakan Minyak Jelantah Guna Mengurangi Pencemaran Lingkungan

\begin{tabular}{|c|l|c|c|c|c|}
\hline No & \multicolumn{1}{|c|}{ PERNYATAAN } & \multicolumn{3}{|c|}{ PRESENTASE } \\
\cline { 2 - 5 } & \multicolumn{1}{|c|}{ SS } & S & TS & STS \\
\hline 1 & $\begin{array}{l}\text { Saya merasa puas dengan kegiatan pengabdian } \\
\text { masyarakat yang diselenggarakan melalui Pelatihan } \\
\text { Pembuatan Sabun Menggunakan Minyak Jelantah } \\
\text { Guna Mengurangi Pencemaran Lingkungan bersama } \\
\text { Universitas Islam Balitar }\end{array}$ & $90 \%$ & $10 \%$ & - & - \\
\hline 2 & $\begin{array}{l}\text { Kegiatan pengabdian masyarakat yang } \\
\text { diselenggarakan melalui Pelatihan Pembuatan Sabun } \\
\text { Menggunakan Minyak Jelantah Guna Mengurangi } \\
\text { Pencemaran Lingkungan bersama Universitas Islam } \\
\text { Balitar sesuai dengan harapan saya }\end{array}$ & $20 \%$ & - & - \\
\hline 3 & $\begin{array}{l}\text { Anggota yang terlibat dalam kegiatan pengabdian } \\
\text { masyarakat melalui Pelatihan Pembuatan Sabun } \\
\text { Menggunakan Minyak Jelantah Guna Mengurangi } \\
\text { Pencemaran Lingkungan memberikan pelayanan } \\
\text { sesuai dengan kebutuhan saya }\end{array}$ & $85 \%$ & $15 \%$ & - & - \\
\hline 4 & $\begin{array}{l}\text { Setiap saya mengajukan } \\
\text { keluhan/pertanyaan/permasalahan oleh anggota yang } \\
\text { terlibat ditindaklanjuti dengan baik }\end{array}$ & $65 \%$ & $30 \%$ & $5 \%$ & - \\
\hline 5 & $\begin{array}{l}\text { Saya berharap kedepannya kegiatan seperti ini } \\
\text { diadakan kembali }\end{array}$ & $85 \%$ & $15 \%$ & - & - \\
\hline
\end{tabular}

Sumber : Pengabdian, 2021

Berdasarkan tabel di atas dapat dijelaskan sebagai berikut :

1. Peserta pengabdian merasa puas dengan kegiatan pengabdian masyarakat yang diselenggarakan melalui Pelatihan Pembuatan Sabun Menggunakan Minyak Jelantah Guna Mengurangi Pencemaran Lingkungan bersama Universitas Islam Balitar. Hal ini dibuktikan dengan hasil angket yaitu sebanyak 90\% Sangat Setuju dan sebesar $10 \%$ Setuju.

2. Kegiatan pengabdian masyarakat yang diselenggarakan melalui Pelatihan Pembuatan Sabun Menggunakan Minyak Jelantah Guna Mengurangi Pencemaran Lingkungan bersama Universitas Islam Balitar sesuai dengan harapan peserta. Hal ini dibuktikan dengan hasil angket yaitu sebanyak 80\% Sangat Setuju dan sebesar $20 \%$ Setuju.

3. Anggota yang terlibat dalam kegiatan pengabdian masyarakat melalui Pelatihan Pembuatan Sabun Menggunakan Minyak Jelantah Guna Mengurangi Pencemaran 
Lingkungan memberikan pelayanan sesuai dengan kebutuhan peserta pengabdian. Hal ini dibuktikan dengan hasil angket yaitu sebanyak 85\% Sangat Setuju dan sebesar $15 \%$ Setuju.

4. Setiap peserta pengabdian mengajukan keluhan/pertanyaan/permasalahan oleh anggota yang terlibat ditindaklanjuti dengan baik. Hal ini dibuktikan dengan hasil angket yaitu sebanyak 65\% Sangat Setuju dan sebesar 30\% Setuju. Sedangkan sebanyak 5\% Tidak Setuju.

5. Para peserta berharap kedepannya kegiatan seperti ini diadakan kembali. Hal ini dibuktikan dengan hasil angket yaitu sebanyak 85\% Sangat Setuju dan sebesar 15\% Setuju.

Jadi, pelatihan pembuatan sabun menggunakan minyak jelantah guna mengurangi pencemaran lingkungan sangat mudah dilakukan dengan alat dan bahan yang tersedia di rumah tangga. Selain itu, volume minyak jelantah yang terdapat di Desa Blimbing juga mendukung produksi pembuatan sabun sehingga peserta dapat dengan mudah mengaplikasikan keterampilan yang mereka dapat untuk diterapkan di rumah. Pada proses evaluasi, terlihat kemampuan peserta meningkat dalam pelatihan pembuatan sabun menggunakan minyak jelantah guna mengurangi pencemaran lingkungan, terlihat dari jawaban peserta yang mayoritas sangat setuju dengan diadakannya kegiatan pengabdian masyarakat ini.

\section{KESIMPULAN}

Program pengabdian masyarakat tentang pelatihan pembuatan sabun menggunakan minyak jelantah guna mengurangi pencemaran lingkungan cukup menarik dan sangat jarang ditemu. Melalui program pengabdian masyarakat yang sudah dilaksanakan, sebagian besar masyarakat sangat mengapresiasi pembuatan sabun dari minyak jelantah. Selain dapat mengurangi jumlah limbah minyak jelantah yang ada di masyarakat, kegiatan ini juga dapat mengolah limbah yang sebelumnya tidak bermanfaat menjadi barang yang bernilai guna. Pembuatan sabun dari minyak jelantah ini diharapkan dapat menjadi produk khas masyarakat Desa Blimbing, Kecamatan Rejotangan, Kabupaten Tulungagung.

\section{UCAPAN TERIMA KASIH}

Tim pengabdian kepada masyarakat mengucapkan terimakasih kepada Universitas Islam Balitar Blitar yang telah memberikan dana sehingga dapat terlaksananya kegiatan 
pengabdian ini. Kemudian kami juga berterimakasih kepada peserta yang telah dengan senang hati mengikuti kegiatan pengabdian ini.

\section{DAFTAR PUSTAKA}

Anastasia, F. (2018). Gambaran Perilaku Ibu Rumah Tangga terhadap Penggunaan Minyak Goreng Berulang Kali di Desa Serbelawan Kecamatan Dolok Batu Nanggar Kabupaten Simalungun Tahun 2017.

Hanjarvelianti, S., \& Kurniasih, D. (2020). Pemanfaatan Minyak Jelantah dan Sosialisasi Pembuatan Sabun Dari Minyak Jelantah Pada Masyarakat Desa Sungai Limau Kecamatan Sungai Kunyit-Mempawah. BULETIN AL-RIBAATH, 17(1), 26-30.

Hanum, Y. (2016). Dampak bahaya makanan gorengan bagi jantung. Jurnal Keluarga Sehat Sejahtera, 14(2).

Haryono, H., Sirin Fairus, S. F., Yavita Sari, Y. S., \& Ika Rakhmawati, I. R. (2010). Pengolahan Minyak Goreng Kelapa Sawit Bekas menjadi Biodiesel Studi Kasus: Minyak Goreng Bekas dari KFC Dago Bandung. Pengolahan Minyak Goreng Kelapa Sawit Bekas menjadi Biodiesel Studi Kasus: Minyak Goreng Bekas dari KFC Dago Bandung.

Ketaren, S. (1986). Minyak dan Lemak Pangan. Penerbit UI Press. Jakarta. Lestari, P. P., 2010. Pemanfaatan Minyak Goreng Jelantah pada Pembuatan Sabun Cuci Piring Cair. Medan: Thesis diajukan pada Fakultas Teknik, Universitas Sumatera Utara.

Mardiana, S., Mulyasih, R., Tamara, R., \& Sururi, A. (2020). Pemanfaatan Limbah Rumah Tangga Minyak Jelantah Dengan Ekstrak Jeruk Dalam Perspektif Komunikasi Lingkungan Di Kelurahan Kaligandu. Jurnal SOLMA, 9(1), 92-101.

(C) 2021 by authors. Content on this article is licensed under a Creative Commons Attribution 4.0 International license. (http://creativecommons.org/licenses/by/4.0/). 